\title{
ANALISIS PENERAPAN AKUNTANSI PAJAK PENGHASILAN PASAL 23 PADA PERUSAHAAN JASA PERBANKAN
}

\author{
B. Anggun Hilendri Lestari \\ Fakultas Ekonomi Dan Bisnis Universitas Mataram \\ hilendria@unram.ac.id \\ L. Takdir Jumaidy \\ Fakultas Ekonomi Dan Bisnis Universitas Mataram \\ takdirjumaidy@yahoo.com \\ D. Tiallurra Della Nabila \\ Fakultas Ekonomi Dan Bisnis Universitas Mataram \\ tialurradellanabila@unram.ac.id

$\begin{array}{ll}\text { Diterima } & : 31 \text { Maret } 2020 \\ \text { Direview } & : \text { 19 Mei } 2020 \\ \text { Diterima } & : 4 \text { Juni } 2020\end{array}$

\begin{abstract}
This study aims to determine the application of income tax accounting article 23 in the business activities of Mataram BTN Bank. The results of the study explained that Mataram BTN Bank has approved the payment of income tax article 23 on vehicle rental in accordance with applicable tax regulations and has recorded accounting for vehicle rental costs and taxes on vehicle rental, calculates tax on vehicle rental, tax payment and tax reporting.
\end{abstract}

Keywords: tax accounting, income tax

\begin{abstract}
Abstrak
Penelitian ini bertujuan untuk mengetahui penerapan akuntansi pajak penghasilan pasal 23 dalam kegiatan usaha Bank BTN Cabang Mataram. Hasil penelitian menjelaskan bahwa Bank BTN Cabang Mataram sudah memenuhi kewajiban perpajakan terkait pajak penghasilan pasal 23 atas sewa kendaraan sesuai peraturan perpajakan yang berlaku dan telah melakukan pencatatan akuntansi biaya sewa kendaraan dan pajak penghasilan atas sewa kendaraan, perhitungan pajak penghasilan atas sewa kendaraan, penyetoran pajak penghasilan atas sewa kendaraan dan pelaporan pajak.

Kata kunci: akuntansi, pajak penghasilan
\end{abstract}




\section{PENDAHULUAN}

Pajak sebagai salah satu sumber penerimaan penting bagi negara digunakan untuk membiayai pengeluaran negara. Pembayaran pajak adalah wujud kewajiban warga negara untuk berperan secara langsung dan bersama-sama untuk iuran dalam rangka pembiayaan dan pembangunan nasional. Diperlukan kesadaran serta pemahaman wajib pajak tentang pajak guna memenuhi kebutuhan dan untuk menyelenggarakan kepentingan negara (Permatasari et al., 2016).

Pajak Penghasilan (PPh) merupakan pajak negara yang dikenakan terhadap subjek pajak atas penghasilan yang diterima atau diperolehnya dalam tahun pajak. Pajak penghasilan dikenakan terhadap orang atau badan usaha yang memperoleh penghasilan di Indonesia (Hendra et al., 2014). Pajak Penghasilan Pasal 23 merupakan Pajak Penghasilan yang dipotong atas penghasilan yang diterima atau diperoleh Wajib Pajak dalam negeri dan Bentuk Usaha Tetap yang berasal dari modal, penyerahan jasa, atau penyelenggaraan kegiatan selain yang telah dipotong Pajak Penghasilan Pasal 21, yang dibayarkan atau terutang oleh badan pemerintah atau subjek pajak dalam negeri, penyelenggara kegiatan, Bentuk Usaha Tetap atau perwakilan perusahaan luar negeri lainnya (Hendra et al., 2014).

Akuntansi dan perpajakan saat ini tidak dapat dipisahkan, karena baik dari sudut pandang pemerintah maupun perusahaan sama-sama memerlukan perhitungan sesuai ketentuan yang berlaku terhadap pembukuan perusahaan, agar nantinya pajak dapat dibayar tanpa merugikan masing-masing pihak, baik pemerintah maupun perusahaan itu sendiri (Hendra et al., 2014). Akuntansi Pajak merupakan suatu proses pencatatan, penggolongan dan pengikhtisaran suatu transaksi keuangan kaitannya dengan kewajiban perpajakan dan diakhiri dengan pembuatan laporan keuangan fiskal sesuai dengan ketentuan dan peraturan perpajakan 
yang terkait sebagai dasar pembuatan Surat Pemberitahuan Tahunan (Supriyanto : 1).

PT Bank Tabungan Negara merupakan salah satu perusahaan milik negara atau lebih dikenal dengan istilah Badan Usaha Milik Negara (BUMN) yang mana dalam menjalankan kegiatan operasionalnya membutuhkan armada, oleh karena itu PT Bank Tabungan Negara menyediakan banyak kendaraan yang dapat digunakan untuk keperluan usahanya. Sebagian dari armada tersebut merupakan kendaraan yang disewa oleh PT Bank Tabungan Negara yang mana dalam kegitan sewa menyewa tersebut menimbulkan transaksi yang terkait dengan perpajakan.

Jika dicermati dari fenomena tersebut maka penelitian ini bertujuan untuk mengetahui penerapan akuntansi pajak penghasilan pasal 23 dalam kegiatan usaha PT Bank Tabungan Negara, sehingga hasil penelitian ini nantinya dapat memberikan gambaran penerapan akuntansi pajak akuntansi pajak penghasilan pasal 23 pada perusahaan jasa perbankan khususnya PT Bank Tabungan Negara.

\section{TELAAH LITERATUR DAN PENGEMBANGAN HIPOTESIS}

\section{Konsep Dasar Akuntansi}

Jusup (2014:4) menjelaskan akuntansi adalah sistem informasi yang mengukur aktivitas bisnis, mengolah data menjadi laporan, dan mengkomunikasikan hasilnya kepada para pengambil keputusan. Rudianto (2008:4) menjelaskan akuntansi adalah sebuah sistem informasi yang menghasilkan informasi keuangan kepada pihak-pihak yang berkepentingan mengenai aktivitas ekonomi dan kondisi suatu perusahaan.

Menurut Rudianto (2008:5), pengguna informasi akuntansi antara lain: kreditor, pemerintah, calon Investor, pemasok (supplier) Pemilik/pemegang saham, manajer produksi, manajer pemasaran, berbagai pihak internal perusahaan lainnya, memerlukan data dan informasi keuangan lainnya yang harus disediakan oleh akuntansi. Akuntansi pada dasarnya harus mengidentifikasikan data mana yang 
berkaitan atau relevan dengan keputusan yang akan diambil, memproses atau menganalisis data yang relevan mengolah data menjadi informasi yang dapat digunakan untuk pengambilan keputusan.

\section{Konsep Dasar Perpajakan}

\section{Pengertian dan Fungsi Pajak}

Pengertian pajak yang dikemukakan oleh Adriani yang kemudian telah diterjemahkan oleh Brotodiharjo dalam Purwono (2010) adalah iuran kepada negara (yang dapat dipaksakan) yang terutang oleh mereka yang wajib membayarnya menurut peraturan, tanpa mendapat prestasi-kembali yang langsung dapat ditunjuk, dan yang gunanya adalah untuk membiayai pengeluaran umum terkait dengan tugas negara dalam menyelenggarakan pemerintahan.

Menurut Undang-Undang No 28 tahun 2007 pasal 1, pajak adalah kontribusi wajib kepada negara yang terutang oleh orang pribadi atau badan yang bersifat memaksa berdasarkan Undang-undang, dengan tidak mendapatkan imbalan secara langsung dan digunakan untuk keperluan negara bagi sebesar-besarnya kemakmuran rakyat.

Berdasarkan ciri-ciri yang melekat pada pengertian pajak (Waluyo, 2013:3), fungsi pajak dibagi menjadi dua yaitu:

a. Fungsi Budgetair (Sumber Keuangan Negara)

Pajak berfungsi menjadi salah satu sumber penerimaan pemerintah untuk membiayai pengeluaran baik rutin maupun pembangunan. Sebagai contoh: Pajak Penghasilan (PPh), Pajak Pertambahan Nilai (PPN) dan Pajak Penjualan atas Barang Mewah (PPnBM) dan lain-lain.

b. Fungsi Regularend (Pengatur)

Pajak berfungsi sebagai alat untuk mengatur atau melaksanakan kebijakan pemerintah dalam bidang sosial dan ekonomi, serta mencapai tujuantujuan tertentu di luar bidang keuangan. Sebagai contoh dikenakannya pajak yang lebih tinggi terhadap barang mewah. 


\section{Dasar Hukum Pajak Penghasilan Pasal 23}

a) Keputusan Direktur Jendral Pajak Nomor KEP-170/PJ/2002 tentang Jenis Jasa Lain dan Perkiraan Penghasilan Netto sebagaimana dimaksud dalam Pasal 23 ayat (1) huruf e Undang-undang Nomor 7 Tahun 1983 tentang Pajak Penghasilan.

b) Keputusan Direktur Jendral Pajak Nomor KEP-227/PJ/2002 tanggal 23 April 2002 tentang Tata Cara Pemotongan dan Pembayaran serta Pelaporan Pajak Penghasilan dari Persewaan Tanah dan/atau Bangunan.

c) Undang-undang Nomor 17 Tahun 2000 tentang Pajak Penghasilan sebagaimana telah dengan Undang-undang Nomor 36 Tahun 2008.

d) PMK-24/PMK.03/2008 tentang jasa lain selain jasa yang telah dipotong Pajak Penghasilan pasal 21 yang telah ditetapkan oleh Menteri Keuangan.

\section{Objek Pajak Penghasilan Pasal 23}

Dengan diterbitkannya PMK Nomor 244/PMK.03/2008 sebagai juklak dari UU PPh No. 36 Tahun 2008 yang berlaku mulai 1 Januari 2009. Maka objek dan besaran tarif untuk Pasal 23 menyesuaikan dengan ketentuan tersebut. Ketentuan ini cenderung memaksa WP untuk memiliki NPWP kecuali bila yang bersangkutan memilih dipotong lebih tinggi. Berikut ini adalah ringkasan atas penghasilan dari :

1 Dividen, bunga, royalti, sewa dan penghasilan lain sehubungan dengan penggunaan harta, kecuali sewa dan penghasilan lain sehubungan dengan penggunaan harta yang telah dikenai PPh Final pasal 4 (2), terutang PPh Pasal 23 sebesar 15\% dari jumlah bruto.

2 Atas imbalan sehubungan dengan jasa lain selain jasa yang telah dipotong PPh Pasal 21, dipotong PPh Pasal 23 sebesar 2\% dari jumlah bruto tidak termasuk PPN. 


\section{Penghasilan yang Tidak Dipotong Pajak Penghasilan Pasal 23}

Menurut Supriyanto (2011:56), selain penghasilan di atas, beberapa penghasilan yang dikecualikan dari pemotongan PPh Pasal 23 adalah:

$1 \quad$ Penghasilan yang dibayar atau terutang kepada bank

2 Sewa yang dibayarkan atau terutang sehubungan dengan sewa guna usaha dengan hak opsi

3 Dividen sebagaimana dimaksud dalam Pasal 4 ayat (3) huruf $f$ UU PPh dan dividen yang diterima oleh orang pribadi sebagaimana dimaksud dalam Pasal 17 ayat (2c) UU PPh

4 Bagian laba sebagaimana dimaksud dalam Pasal 4 ayat (3) huruf i UU $\mathrm{PPh}$

5 Sisa hasil usaha koperasi yang dibayarkan oleh koperasi kepada anggotanya

6 Penghasilan yang dibayar atau terutang kepada badan usaha atas jasa keuangan yang berfungsi sebagai penyalur pinjaman dan/atau pembiayaan yang terdiri dari:

a. Perusahaan pembiayaan yang merupakan badan usaha di luar bank dan lembaga keuangan bukan bank yang khusus didirikan untuk melakukan kegiatan yang termasuk dalam bidang usaha lembaga pembiayaan dan telah memperoleh ijin usaha dari Menteri Keuangan

b. BUMN atau BUMD yang khusus didirikan untuk memberikan sarana pembiayaan bagi usaga mikro, menengah dan koperasi, termasuk PT (Persero) Permodalan Madani.

Salah satu perubahan besar yang dilakukan oleh Undang-undang Pajak Penghasilan yang baru saja disetujui oleh rapat paripurna DPR adalah masalah Pajak Penghasilan Pasal 23. Sebelum dikeluarkannya UU No 36 Tahun 2008 sistem pentarifan PPh Pasal 23 masih menggunakan perkiraan penghasilan neto, sehingga kemudian ada istilah tarif efektif, 
sekarang ini telah diganti dengan penerapan tarif langsung kepada penghasilan bruto.

\section{Pemotong Pajak Penghasilan Pasal 23}

Menurut Supriyanto (2011:57), dalam masalah pemotong pajak ini, nampaknya tidak ada perubahan berarti yaitu tetap badan pemerintah, Subjek Pajak badan dalam negeri, penyelenggara kegiatan, bentuk usaha tetap, atau perwakilan perusahaan luar negeri lainnya. Wajib Pajak Orang Pribadi dapat ditunjuk oleh Direktur Jenderal Pajak sebagai pemotong PPh Pasal 23. Ketentuan inipun tak mengalami perubahan. Pihak yang dipotong PPh Pasal 23 tidak mengalami perubahan yaitu Wajib Pajak Dalam Negeri dan Bentuk Usaha Tetap (BUT).

\section{Tarif Bagi Wajib Pajak Tak Ber-NPWP}

Berdasarkan Pasal 23 ayat (1a) Undang-undang Pajak Penghasilan yang baru, Wajib Pajak yang menerima atau memperoleh penghasilan yang merupakan objek pemotongan PPh Pasal 23 dan tidak memiliki Nomor Pokok Wajib Pajak (NPWP), maka besarnya tarif pemotongan PPh Pasal 23 adalah lebih tinggi 100\% (seratus persen) daripada tarif PPh Pasal 23 umumnya. Hal ini dapat ditafsirkan bahwa Jika bagi Wajib Pajak yang berNPWP dikenakan tarif 15\%, maka bagi yang tidak berNPWP akan dikenakan tarif 30\%. Begitu juga jika Wajib Pajak berNPWP dikenakan tarif $2 \%$ maka bagi yang tidak berNPWP menjadi $4 \%$.

\section{Prosedur Pemotongan, Penyetoran dan Pelaporan Pajak Penghasilan Pasal 23}

1. Saat Terutangnya PPh 23

Pemotongan PPh Pasal 23 adalah saat terutangnya PPh Pasal 23. Dalam Undang-undang Nomor 36 Tahun 2008 Pasal 23 ayat (1) disebutkan bahwa "atas penghasilan tersebut dibawah ini dengan nama dan dalam bentuk apapun yang dibayarkan, disediakan untuk dibayar atau telah jatuh tempo pembayarannya oleh badan pemerintah subyek pajak dalam negeri, 
penyelenggara kegiatan bentuk usaha tetap atau perwakilan perusahaan di luar negeri lainnya kepada Wajib Pajak dalam negeri atau bentuk usaha tetap , dipotong pajak oleh pihak wajib dibayarkan."

Saat terutang PPh Pasal 23 menurut Undang-undang Nomor 36 Tahun 2008 yaitu :

a) Saat dibayarkan (cash basis)

b) Saat disediakan untuk dibayarkan (dapat berupa cadangan untuk dibayar)

c) Saat jatuh tempo pembayaran (saat terutang)

d) Penegasan saat terutang PPh Pasal 23 menurut Undang-undang.

\section{Saat Penyetoran}

Pajak Penghasilan Pasal 23 harus disetor oleh Pemotong Pajak selambat-lambatnya tanggal 10 takwin berikutnya setelah bulan saat terutangnya pajak. Dalam hal jatuh tempo penyetoran bertepatan dengan hari libur termasuk hari Sabtu atau hari libur nasional, penyetoran dapat dilakukan pada hari kerja berikutnya.

3. Saat Pelaporan

Pemotong PPh Pasal 23 diwajibkan menyampaikan Surat Pemberitahuan Masa selambat-lambatnya 20 hari setelah Masa Pajak berakhir. Apabila batas akhir pelaporan PPh bertepatan dengan hari libur atau hari libur nasional, maka pelaporan dapat dilakukan pada hari kerja berikutnya.

\section{Akuntansi Perpajakan}

Supriyanto (2011:1), akuntansi Pajak berasal dari dua kata yaitu akuntansi dan pajak. Akuntansi adalah suatu proses pencatatan, penggolongan, pengikhtisaran suatu transaksi keuangan dan diakhiri dengan suatu pembuatan laporan keuangan. Sedangkan pajak adalah iuran atau punggutan wajib yang dipungut oleh pemerintah dari masyarakat (wajib pajak) untuk menutupi pengeluaran rutin negara dan biaya pembangunan tanpa balas jasa yang dapat ditunjuk secara langsung. Jadi, Akuntansi Pajak adalah suatu proses pencatatan, penggolongan dan 
pengikhtisaran suatu transaksi keuangan kaitannya dengan kewajiban perpajakan dan diakhiri dengan pembuatan laporan keuangan fiskal sesuai dengan ketentuan dan peraturan perpajakan yang terkait sebagai dasar pembuatan Surat Pemberitahuan Tahunan.

Akuntansi Pajak merupakan bagian dalam akuntansni yang timbul dari unsur spesialisasi yang menuntut keahlian dalam bidang tertentu. Akuntansi Pajak tercipta karena adanya suatu prinsip dasar yang diatur dalam Undang-Undang Perpajakan dan pembentukannya terpengaruh oleh fungsi perpajakan dalam mengimplementasikan sebagai kebijakan pemerintah. Akuntansi pajak hanya digunakan untuk mencatat transaksi yang berhubungan dengan perpajakan. Tujuan dari akuntansi pajak adalah menetapkan besarnya pajak terutang berdasarkan laporan keuangan yang disusun oleh perusahaan (Agoes: 10).

\section{Perbandingan Pembukuan dan Pencatatan}

Berdasarkan Undang-undang No. 16 Tahun 2009 Pasal 28 Ayat (1) disebutkan bahwa Wajib Pajak orang pribadi yang melakukan kegiatan usaha atau pekerjaan bebas dan Wajib Pajak badan di Indonesia wajib menyelenggarakan pembukuan. Lalu pada Pasal 28 ayat (2) disebutkan bahwa Wajib Pajak yang dikecualikan dari kewajiban menyelenggarakan pembukuan sebagaimana dimaksud pada ayat (1), tetapi wajib melakukan pencatatan adalah Wajib Pajak orang pribadi yang melakukan kegiatan usaha atau pekerjaan bebas yang sesuai dengan ketentuan peraturan perundang-undangan perpajakan diperbolehkan menghitung penghasilan neto dengan menggunakan Norma Penghitungan Penghasilan Neto (NPPN) dan Wajib Pajak orang pribadi yang tidak melakukan kegiatan usaha atau pekerjaan bebas.

Berdasarkan ketentuan diatas jelas bahwa sesungguhnya baik wajib pajak orang pribadi (WPOP) maupun wajib pajak badan (WPB) diwajibkan untuk melakukan pembukuan. Pembukuan merupakan proses pencatatan semua transaksi perusahaan disertai dengan bukti-bukti yang akurat dan diakhiri dengan pembuatan laporan keuangan. 


\section{METODE PENELITIAN}

Penelitian ini termasuk dalam jenis penelitian deskriptif yaitu memberikan gambaran atau mendeskripsikan penerapan akuntansi PPh Pasal 23 yang dilakukan oleh perusahaan dengan Standar Akuntansi Keuangan dan Undang-Undang tentang Pajak Penghasilan. Penelitian ini dilakukan pada PT Bank Tabungan Negara cabang Mataram dikarenakan data dan kelengkapannya dianggap cukup oleh peneliti.

Pengumpulan data dilakukan dengan berbagai cara yakni: observasi, wawancara, dan dokumentasi. Adapun sumber data dalam penelitian ini berupa perhitungan PPh pasal 23 dan penerapan akuntansi perpajakan oleh PT Bank Tabungan Negara cabang Mataram, Standar Akuntansi Keuangan, serta Undang-undang Perpajakan. Adapun prosedur pengolahan data terdiri dari: verifikasi, pengorganisasian data, pencarian kembali, pengurutan, penghitungan, dan pembentukan pengetahuan. Tahap berikutnya adalah menarik kesimpulan penelitian.

\section{haSil PENELITIAN DAN PEMBAHASAN}

\section{Akuntansi Pajak atas Sewa Kendaraan pada PT. Bank Tabungan Negara (Persero) Tbk. Cabang Mataram}

A. Proses Pembayaran Sewa Kendaran kepada PT. Pesona Adi Batara oleh PT. Bank Tabungan Negara (Persero) Tbk. Cabang Mataram

PT. Bank Tabungan Negara memiliki perjanjian kerjasama tentang sewa kendaraan dengan PT. Pesona Adi Batara. Pada tanggal 22 Maret surat tagihan sewa untuk 2 kendaraan berupa mobil merek Avanza periode sewa bulan maret di terima PT. Bank Tabungan Negara dengan total tagihan Rp 9.000.000 (sudah termasuk PPN 10\%). 


\section{Gambar 3 Proses Pembayaran Sewa Kendaraan kepada PT. Pesona Adi Batara}

\begin{tabular}{|c|c|c|c|}
\hline $\begin{array}{c}\text { Surat } \\
\text { Tagihan } \\
\text { Sewa } \\
\text { diterima }\end{array}$ & $\begin{array}{l}\text { Permintaan } \\
\text { Disposisi }\end{array}$ & $\begin{array}{c}\text { Membuat } \\
\text { SPM }\end{array}$ & $\begin{array}{l}\text { SPM } \\
\text { Dicek }\end{array}$ \\
\hline & & Ditransaksi & \\
\hline & & Dijurnal & \\
\hline
\end{tabular}


Proses pembayaran sewa dimulai dari diterimanya surat tagihan sewa oleh sekretaris PT. Bank Tabungan Negara (Persero) Tbk. Cabang Mataram dari PT. Pesona Adi Batara untuk periode bulan maret 2019. Dari surat tagihan sewa tersebut sekretaris mengirim permintaan disposisi ke bagian General Branch Administrator. Permintaan Disposisi diterima oleh General Branch Administrator yang kemudian dibuat SPM (Surat Perintah Membayar) dengan lampiran surat tagihan sewa dan disposisi. SPM dicek oleh bagian Accounting Control Unit apakah rinciannya sudah sesuai atau tidak, apabila tidak sesuai maka SPM kembali ke bagian General Branch Administrator untuk dibuat ulang sesuai dengan rinciannya. Jika SPM sudah sesuai SPM diparaf oleh staff accounting, maka SPM ditandatangani oleh Operation Unit Head untuk meminta persetujuan. Setelah disetujui, Transaction Processing melakukan transaksi ke rekening nasabah menggunakan aplikasi Branch Delivery System, slip kuning SPM dan rinciannya ke Unit Accounting untuk dijurnal melalui aplikasi Branch Delivery System .

B. Pencatatan dan Pemotongan pada PT. Bank Tabungan Negara (Persero) Tbk. Cabang Mataram

Perhitungan pajak penghasilan pasal 23 adalah sebagai berikut :

Biaya sewa : Rp. 9.000.000

Tarif pajak penghasilan pasal 23 : 2\%

Masa pajak : Maret

Tahun : 2019

Baiya sewa bruto $=b$

Biaya sewa neto $=\mathrm{n}$

$\mathrm{n}=\mathrm{b}+\mathrm{PPN}$

Rp. $9.000 .000=b+(10 \% x b)$

Rp. $9.000 .000=100 \% b+10 \% b$

Rp $9.000 .000=110 \% b$

b = Rp. $9.000 .000 \times 100 / 110$

$\mathrm{b}=\mathrm{Rp} 8.181 .818$ (dibulatkan) 
Menurut UU PPh Nomor 36 Tahun 2008 Pasal 23 ayat (1) huruf c mulai 1 Januari 2009 sewa dan penghasilan lain sehubungan dengan penggunaan harta dikenakan PPh 23 sebesar 25

Pemotongan PPh pasal $23=$ Tarif pajak $\mathrm{x}$ penghasilan bruto

$$
\begin{aligned}
& =2 \% \times \operatorname{Rp} 8.181 .818 \\
& =\operatorname{Rp~} 163.636 \text { (dibulatkan) }
\end{aligned}
$$

Atas transaksi sewa ini PT. Bank Tabungan Negara (Persero) Tbk. Cabang Mataram selaku pemotong pajak wajib memotong pajak penghasilan atas sewa kendaraan sebesar Rp 163.636

Biaya sewa Rp 9.000.000

PPh pasal $23 \quad \mathrm{Rp} 163.636$ -

Jumlah yang dibayarkan $\quad$ Rp 8.836.364

Jurnal yang dibuat oleh PT. Bank Tabungan Negara (Persero) Tbk. Cabang Mataram adalah :

Jurnal oleh Accounting

D: Biaya Sewa Kendaraan

Rp 9.000.000

K: Suspend Aplikasi Giro

Rp 8.836.364

K: Utang PPh Pasal 23

Rp $\quad 163.636$

Jurnal oleh TP

D: Suspend Aplikasi Giro

Rp. 8.836.364

K: Rek. PT. PAB

Rp 8.836.364 
C. Proses Saat Penyetoran Pajak Sewa Kendaraan ke Kas Negara oleh PT. Bank Tabungan Negara

\section{Gambar 4 Proses Saat Penyetoran Pajak Sewa Kendaraan ke Kas Negara oleh PT. Bank Tabungan Negara (Persero) Tbk. Cabang Mataram}

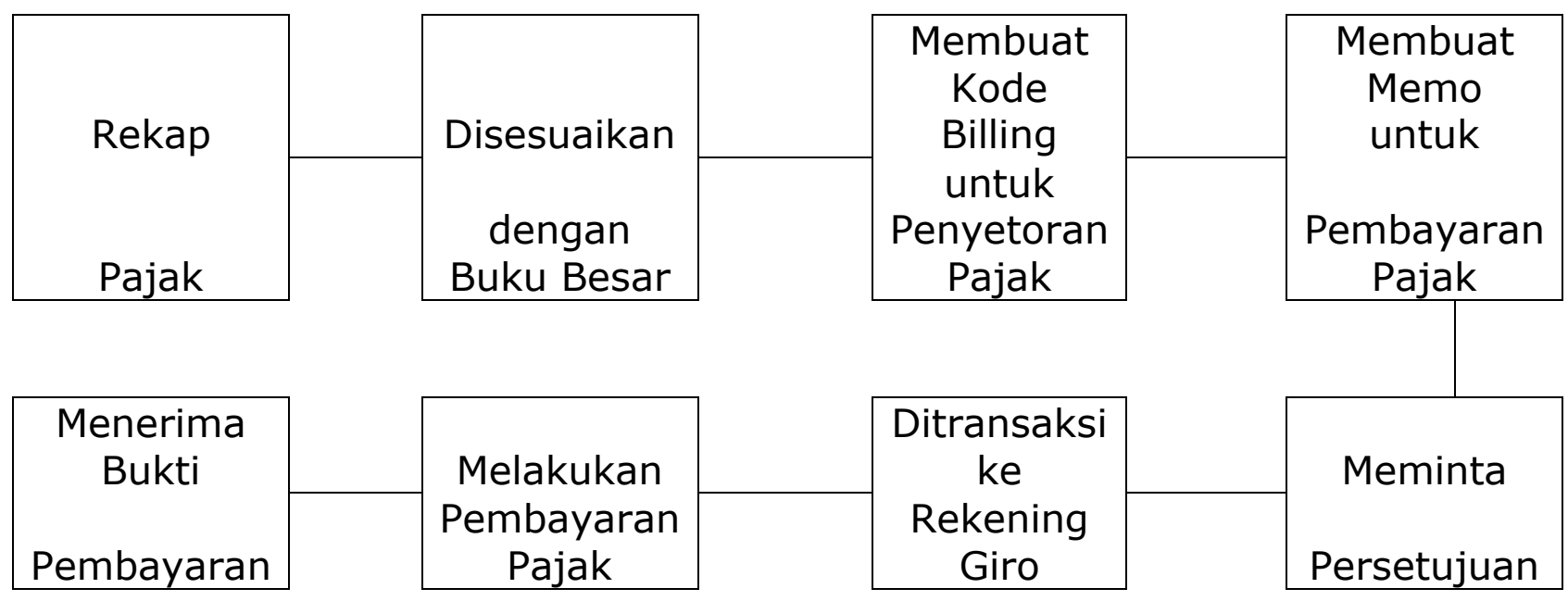


Proses peyetoran pajak sewa kendaraan dimulai dari Transaction Processing merekap data PPh Pasal 23 atas sewa kendaraan. Data rekapan PPh Pasal 23 tersebut dibawa ke Accounting Control Unit untuk disesuaikan dengan jumlah yang tertera pada buku besar. Setelah jumlah antara rekap pajak yang dilakukan Transaction Processing dengan jumlah yang ada di buku besar melalui aplikasi Branch Delivery System oleh Accounting Control Unit sudah sesuai, Transaction Processing membuat kode billing untuk penyetoran pajaknya secara online melalui sse.pajak.go.id. Cetakan kode billing tersebut dibuat sebagai lampiran memo untuk pembayaran pajak, meminta persetujuan Operation Unit Head untuk ditransaksi oleh Transaction Processing ke rekening penampungan Giro PT. Bank Tabungan Negara (Persero) Tbk. Cabang Mataram. Transaction Processing melakukan penyetoran ke teller dengan membawa memo tersebut untuk mendapat cetakan bukti penyetoran pajak penghasilan pasal 23 atas sewa kendaraan.

D. Penyetoran Pajak Sewa Kendaraan ke Kas Negara oleh PT. Bank Tabungan Negara

Penyetoran pajak dilakukan sampai dengan tanggal 10 bulan berikutnya setelah masa pajak oleh PT. Bank Tabungan Negara (Persero) Tbk. Cabang Mataram.

Junal yang dibuat setelah pembayaran pajak dilakukan Junal oleh Accounting Control Unit

D: Utang PPh Pasal 23 Rp 163.636

K: Suspend Aplikasi Giro Rp 163.636

Jurnal oleh Transaction Processing

D: Suspend Aplikasi Giro Rp 163.636

K: Rek. Kas Negara Rp 163.636

E. Pelaporan Pajak Sewa Kendaraan ke Kas Negara oleh PT. Bank Tabungan Negara (Persero) Tbk. Cabang Mataram 
Lestari, Jumaidy \& Nabila: Analisis Penerapan Akuntansi ..

Pelaporan pajak dilakukan dengan menyampaikan SPT (SPT) Masa PPh Pasal 23 secara online melalui situs resmi Direktorat Jendral Pajak. 


\section{Gambar 5 Pelaporan Pajak Sewa Kendaran ke Kas Negara oleh PT. Bank Tabungan Negara} (Persero) Tbk. Cabang Mataram

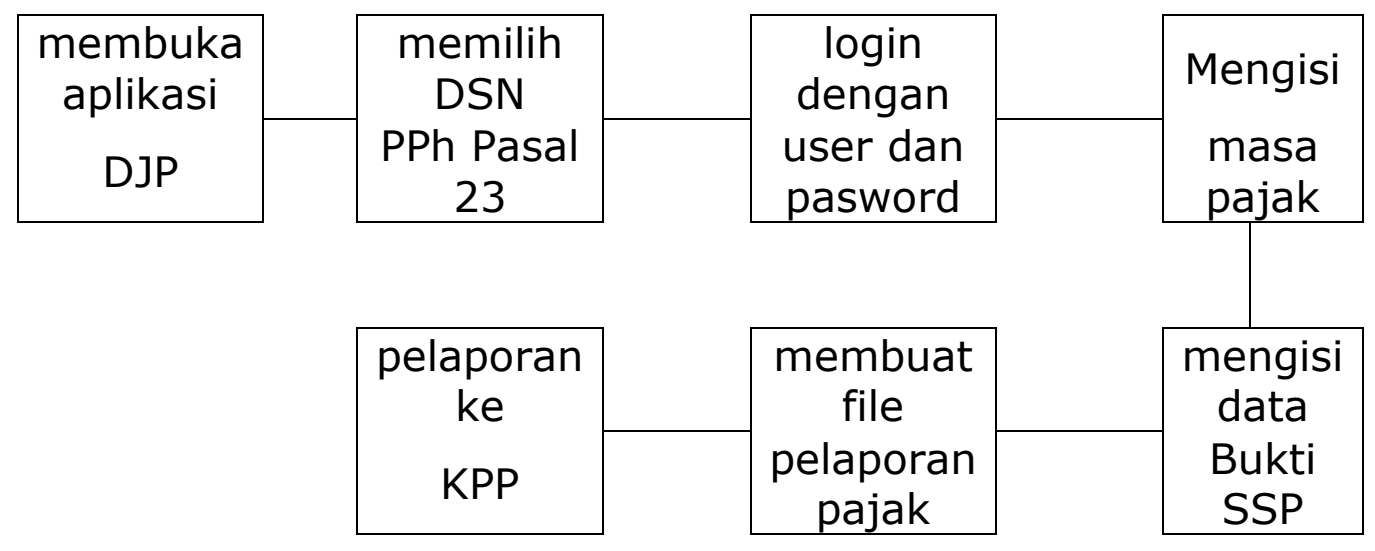


Pengisian data pelaporan pajak dilakukan secara online melalui aplikasi resmi Direktorat Jendral Pajak, memilih Pajak Penghasilan Pasal 23 untuk dilaporkan. Kemudian login dengan user dan password yang dimiliki oleh PT. Bank Tabungan Negara (Persero) Tbk. Cabang Mataram dan muncul form masa pajak yang akan dilaporkan yaitu masa pajak untuk bulan Maret tahun 2019. Muncul daftar PPh Pasal 23 yang telah di potong oleh PT. Bank Tabungan Negara (Persero) Tbk. Cabang Mataram, yang diisi dengan nomor bukti surat setoran pajak yang telah didapat pada saat penyetoran pajak. Setelah itu buat file lapor data dan simpan untuk pelaporan pajak ke kantor pelayanan pajak. File yang buat dibawa ke kantor pelayanan pajak untuk pelaporan pajak. Kantor Pelayanan Pajak memberikan file pelaporan pajak diberikan dalam bentuk CSV oleh kantor pelayanan pajak sebagai bukti PT. Bank Tabungan Negara (Persero) Tbk. Cabang Mataram sebagai pemotong telah melaporkan kewajiban pajak PT. Pesona Adi Batara ke Kantor Pelayanan Pajak.

\section{SIMPULAN}

Berdasarkan hasil penelitian dapat disimpulkan bahwa PT. Bank Tabungan Negara (Persero) Tbk. Cabang Mataram sudah memenuhi kewajiban perpajakan terkait pajak penghasilan pasal 23 atas sewa kendaraan sesuai peraturan perpajakan yang berlaku dan telah melakukan pencatatan akuntansi biaya sewa kendaraan dan pajak penghasilan atas sewa kendaraan, perhitungan pajak penghasilan atas sewa kendaraan, penyetoran pajak penghasilan atas sewa kendaraan dan pelaporan pajak. Proses Pencatatan, pembayaran dan pelaporan pajak atas sewa kendaraan melibatkan beberapa unit oleh pihak PT. Bank Tabungan Negara (Persero) Tbk. Cabang Mataram telah menerapkan pengendalian internal dengan baik untuk menghindari terjadinya kesalahan yang dapat merugikan banyak pihak. Pencatatan akuntansi dilakukan dengan menggunakan aplikasi Branch Delivery System. 
Berdasarkan kesimpulan dapat diberikan saran agar Cabang Mataram agar PT. Bank Tabungan Negara (Persero) Tbk. Cabang Mataram mempertahankan proses akuntansi pajak yang telah dilaksanakan dengan pengendalian internal yang baik melalui pemanfaatan teknologi informasi yang digunakan.

\section{DAFTAR PUSTAKA}

Jusup.Al Haryono. 2012. "Dasar-Dasar Akuntansi-Jilid 1". Yogyakarta : STIE YKPN

Keputusan Direktur Jendral Pajak Nomor KEP-170/PJ/2002 tentang Jenis Jasa Lain dan Perkiraan Penghasilan Netto

Keputusan Direktur Jendral Pajak Nomor KEP-227/PJ/2002 tanggal 23 April 2002 tentang Tata Cara Pemotongan dan Pembayaran serta Pelaporan Pajak Penghasilan dari Persewaan Tanah dan/atau Bangunan.

PMK Nomor 244/PMK.03/2008 sebagai juklak dari UU PPh No. 36 Tahun 2008 tentang jasa lain selain jasa yang telah dipotong Pajak Penghasilan pasal 21 yang telah ditetapkan oleh Menteri Keuangan.

Purwono,Herry. 2010. "Dasar-Dasar Perpajakan \& Akuntansi Pajak". Jakarta : Erlangga

Puspitawati,Lilis.2010. "Sistem Informasi Akuntansi". Bandung : Graha Ilmu Supramono. 2015. "Perpajakan Indonesia Mekanisme \& Perhitungan". Yogyakarta : Andi Yogyakarta

Supriyanto,Eddy.2011. "Akuntansi Perpajakan". Yogyakarta : Graha Ilmu Undang-undang No. 16 Tahun 2009 Tentang Penetapan Peraturan Pemerintah Pengganti Undang-Undang Nomor 5 Tahun 2008 Tentang Keempat Atas Undang-Undang Nomor 6 Tahun 1983 Tentang Ketentuan Umum Dan Tata Cara Perpajakan Menjadi Undang-Undang 
Lestari, Jumaidy \& Nabila: Analisis Penerapan Akuntansi ...

Undang-undang Nomor 36 Tahun 2008 Tentang Pajak Penghasilan

Undang-undang Nomor 17 Tahun 2000 tentang Pajak Penghasilan sebagaimana telah dengan Undang-undang Nomor 36 Tahun 2008.

Undang-Undang No 28 tahun 2007 Tentang Ketentuan Umum Dan Tata Cara Perpajakan (KUP) adalah peraturan perpajakan yang mengatur tentang Ketentuan Umum Dan Tata Cara Perpajakan bagi wajib pajak yang mulai berlaku tanggal 1 Januari 2008

Waluyo,Didik Budi. 2009. "Petunjuk Pemotongan Pajak Penghasilan Pasal 21/26".Jakarta : DBW Tax Center 